Asian J. Med. Biol. Res. 2016, 2 (1), 95-106; doi: 10.3329/ajmbr.v2i1.27574

\author{
Asian Journal of \\ Medical and Biological Research \\ ISSN 2411-4472 (Print) 2412-5571 (Online) \\ www.ebupress.com/journal/ajmbr
}

\title{
Article
}

\section{An efficient protocol for in vitro regeneration of Stevia rebaudiana}

\author{
Sheikh Rashel Ahmed*, Md. Moniruzzaman Shohag Howlader, Pijush Sutradhar and Sabina Yasmin \\ Department of Biotechnology, Faculty of Agriculture, Bangladesh Agricultural University, Mymensingh, 2202, \\ Bangladesh
}

*Corresponding Author: Sheikh Rashel Ahmed, Department of Biotechnology, Faculty of Agriculture, Bangladesh Agricultural University, Mymensingh 2202, Bangladesh. Mobile: +8801925652984; E-mail: rashel_gebcu@yahoo.com.

Received: 07 March 2016/Accepted: 23 March 2016/Published: 31 March 2016

\begin{abstract}
An efficient high frequency plant regeneration protocol through direct organogenesis was developed for Sevia rebaudiana. Shoot tips containing axillary buds were used as an explant and inoculated on Murashige and Skoog's (MS) medium containing 3\% (w/v) sucrose, $0.6 \%(\mathrm{w} / \mathrm{v})$ agar supplemented with various concentrations of benzy-ladenine (BA), kinetin (Kn) and thidiazuron (TDZ).. BAP proved to be a better choice than $\mathrm{Kn}$ and the maximum number of shoots (3.75) was obtained on $2.0 \mathrm{mgL}^{-1} \mathrm{BAP}$ concentration. Considering all parameters, combination of BAP and Kn gave comparatively better performance than single BAP or Kn. TDZ was effective for multiple shooting. Though, $1.5 \mathrm{mgL}^{-1} \mathrm{TDZ}$ gave the best number of shoots (14.5), but 1.0 $\mathrm{mgL}^{-1} \mathrm{TDZ}$ gave best performance in response to all parameters under study. The highest number of shoots was obtained in $60 \mathrm{mlL}^{-1}$ coconut water, but $40 \mathrm{mlL}^{-1}$ coconut water gave the best result to all parameters. Root induction was tested by using two auxins namely NAA and IBA at different concentrations $\left(1.0,1.5,2.0 \mathrm{mgL}^{-1}\right)$ on the MS medium. IBA at $1.0 \mathrm{mgL}^{-1}$ increased the rooting response $(66.67 \%)$, number of roots (7.0) and root length $(2.9 \mathrm{~cm})$. Higher concentration of IBA and NAA $\left(2.0 \mathrm{mgL}^{-1}\right)$ showed poor results of rooting response $(33.33 \%)$.
\end{abstract}

Keywords: in vitro regeneration, Stevia rebaudiana

\section{Introduction}

Stevia rebaudiana is one of the 154 species in the genus of Stevia. It is a herbaceous perennial shrub belonging to the sunflower family Asteraceae which is indigenous to Brazil and Paraguay (Uddin et al., 2006; Alhady, 2011). It is commonly known as candy leaf, sweet leaf, sweet herb or honey leaf which is estimated to be 300 times sweeter than sugar cane (Chalapathi and Thimmegowda, 1997). S. rebaudiana has also been used as a medicinal plant to cure many diseases like obesity, hypertension, heartburn, hypogylycemia and to lower the uric acid levels (Ahmed et al., 2007). Stevia has a potential commercial value. So, with the approval of FDA committee for consumption of Stevia as a food supplement for sweetening, it is commercially cultivated in Brazil, Uruguay, Central America, Israel, Thailand, Australia, Japan, Korea and China. Stevia largest producer is China with about 13, 400 ha of planted area and about 40000 tons of Stevia leaves every day. In recent years, Stevia products find widespread use in the food industry (Savita et al., 2004; Midmore and Rank, 2006). Conventionally, it is propagated by seeds or stem cuttings. Propagation through seed is not adequate owing to low seed germination percentage. The stem cutting method has limitations such as low number of new plants and destruction of the donor plant (Razak et al., 2014). To overcome these obstacles, tissue culture techniques is commonly used as a viable alternative for the production of disease free plants within a shorter period of time with less cost (Satpathy and Das, 2010). The hormonal balance between auxins and cytokinins can regulate the formation of roots, shoots and callus tissue in vitro (Papry et al., 2015). Furthermore, the hormones auxins and cytokinins have a multitude of complex interactions, which control plant development. 


\section{Materials and Methods}

The research work was conducted at laboratory of the Department of biotechnology and physics with a common help of central laboratory, Bangladesh Agricultural University, Mymensingh during the period from July to November, 2015. Shoot tips were used as explants for shoot regeneration. All the explants were collected from 46 month old yard grown plants from physics department of BAU. Five experiments with different treatments were carried out in this research. Single or combined effect of cytokinin (BAP or Kn), effect of thidiazuron, effect of coconut water concentrations on shoot proliferation and effect of auxin (NAA and IBA) on root induction of Stevia rebaudiana was observed in these experiments.

\subsection{Preparation of MS medium}

MS medium was used to detect the effect of hormone and coconut water concentration on the shoot and root development of natural sweetener containing herb Stevia rebaudiana

Following procedure was maintained to prepare $1000 \mathrm{ml}$ of MS media with care-

a) The appropriate amount of each of stock solutions (macrosalts, microsalts, Fe-EDTA, vitamins, Myoinositol)

b) $500 \mathrm{ml}$ distilled water was added in the flask to dissolve all the ingredients on a heater cum magnetic stirrer.

c) $30 \mathrm{gm}$ sucrose was added to this solution and agitated gently to dissolve completely.

d) Different concentrations of hormonal supplements were added to the solution either in single or in combinations as required and mixed well.

e) The whole mixer was then made up to $1 \mathrm{~L}$ with adding distilled water.

f) The $\mathrm{pH}$ of the liquid medium was adjusted to $5.75-5.80$ with the aid of $0.1 \mathrm{~N} \mathrm{HCl}$ or $0.1 \mathrm{~N} \mathrm{NaOH}$, wherever it necessary. This operation was done using a digital $\mathrm{pH}$ meter.

g) $\quad 0.6 \%$ agar was added to the liquid medium to make solid medium. The culture medium was dispensed into culture vial $(20 \mathrm{ml} / \mathrm{vial})$

h) Medium was finally sterilized by autoclaving.

\subsection{Sterilization}

Contamination can be occurred by air, explants, contaminated vials or workers. Elimination of microbiological organisms for aseptic condition is mandatory, to conduct a successful in vitro regeneration process. Both MS were poured in $25 \mathrm{ml}$ small sterilized vials which was autoclaved at $121^{\circ} \mathrm{C}$ at $1.16 \mathrm{~kg} / \mathrm{cm}$ for 20 minutes for sterilization. Sterilization of glassware and other instruments achieved by following approaches: (i) dry heat, (ii) flame sterilization, (iii) autoclaving, (iv) wiping with $70 \%$ ethanol. Further sterilization was done under aseptic conditions in a laminar air flow cabinet.

\subsubsection{Surface sterilization of plant material}

The explants were cut into small pieces (about $1.5 \mathrm{~cm}$ long) and initially washed under running tap water for 6-7 mins. Explants were rinsed with distilled water containing few drops of savlon and tween-20 with continuous shaking for 10-15 seconds and washed thoroughly with distilled water. They were then taken under laminar air flow cabinet to soak them with $70 \%$ alcohol for 10 seconds and washed 3-4 times with autoclaved distilled water. Finally, explants were immersed in $0.1 \%$ commercial $\mathrm{HgCl}_{2}$ solution in combination with 2-3 drops tween-20 for 4-5 minutes with continuous shaking followed by adding sterilized distilled water 6-7 times to drain out last particle of $\mathrm{HgCl}_{2}$.

\subsection{Explant inoculation technique}

The explants were inoculated on MS medium fortified with cytokinins (BAP, Kinetin and TDZ in single or in combination) for shoot induction and auxins (NAA and IBA) for root induction. The $\mathrm{pH}$ of the media was adjusted at 5.75-5.80 before gelling the medium with 0.6\% agar. The cap of vial was holded by little finger and was flame sterilized. During inoculation special care was taken so that the explants must touch the medium equally and not dept into the medium.

\subsection{Incubation}

After inoculating the explants onto culture media, cultures were incubated on culture rack at $25 \pm 2^{0} \mathrm{C}$ constant temperature under the white $25 \pm 2^{0} \mathrm{C}$. The photoperiod was maintained as 16 hours light and 8 hours dark. 


\subsection{Collection of data}

Data were collected on the effect of different treatments on direct shoot and root regeneration. For shoot induction, data were recorded in terms of days required for shoot initiation, percentage of shoot regeneration, shoot length $(\mathrm{cm})$ and number of shoots per explants. The days required for shoot initiation, percentage of rooted shoots, number of roots formed, average root length $(\mathrm{cm})$ were determined after 3 weeks of culture on the rooting medium.

\subsection{Statistical analysis}

The data for the character under present study were statistically analyzed wherever applicable. The experiment was conducted in growth room and arranged in completely randomized design (CRD). The analysis of variance of different characters was performed and means were compared by the Duncan's multiple range test (DMRT).

\section{Results and Discussion}

\subsection{Effect of cytokinin (BAP or Kn) on shoot proliferation of Stevia rebaudiana after 4 week}

\subsubsection{Number of shoots explant ${ }^{-1}$}

The significant variation data of shoot regeneration have been presented in Table 1 and Figure 1 where it was found that the treatment $2 \mathrm{mgL}^{-1}$ BAP produced the highest number of shoot explant ${ }^{-1}$ (3.750) followed by 3 $\mathrm{mgL}^{-1}$ BAP (3.25). On the other hand, the treatment $\mathrm{T}_{0}$ (control) showed the lowest number of shoot explant ${ }^{-1}$ (1.664) which also differed significantly from all other treatments. To a certain extent, with increasing concentration of BAP and kinetin, an increase in number of multiple shoots was observed. Higher concentrations of BAP in the medium resulted in a reduced number of shoots. By comparing all parameters of all treatments, $2 \mathrm{mgL}^{-1} \mathrm{BAP}$ gave best performance. This result partially supported Mehta et al., (2012). Between the two hormone (BAP and Kn), BAP induced higher number of shoots than Kn. Among the different treatment of Kinetin, the lowest number of shoots (2.332) was achieved from $1 \mathrm{mgL}^{-1} \mathrm{Kn}$ which was closely related to BAP (1 or $\left.2 \mathrm{mgL}^{-1}\right)$ and $\mathrm{Kn}\left(2\right.$ or $\left.4 \mathrm{mgL}^{-1}\right)$. Mathur and Begum (2015) showed enhanced shoot proliferation on MS medium containing BAP and $\mathrm{Kn}$ in the range 1.0-5.0 mgL $\mathrm{m}^{-1}$. BAP at its $3.0 \mathrm{mgL}^{-1}$ concentration evoked best response. According to Pawar et al., (2015) the higher number of shoots per explants (eight) was obtained from nodal explants as compared to shoot tip (six) on the medium i.e. (MS $+2 \mathrm{mgL}^{-1} \mathrm{BAP}$ ). Kavitha et al., (2012) reported that shoot tip explants cultured on MS medium supplemented with $\mathrm{Kn}\left(3.0 \mathrm{mgL}^{-1}\right)$ produced the maximum number of shoots $(12.6 \pm 0.68)$ per explants. This indicates that these explants contain sufficient endogenous level of auxins or capable of its de novo synthesis which can induce shoot formation even in a medium containing cytokinin alone (Julliard et al., 1992).

Cytokinins, especially BAP, are reported to overcome apical dominance, release lateral buds from dormancy and promote shoot formation (George, 1993). Superiority of BAP in inducing multiple shoot formation has also been reported for a number of plants e.g. Tridax procumbens (Sahoo, Chand 1998), Cypripedium flavum (Yan et al., 2006) and Medicago truncatula (Neves et al., 2001). Kn alone was not very efficient in inducing shoot multiplication in the present experiments. Low rate of multiplication in medium containing $\mathrm{Kn}$ has been observed in a number of plants e.a. Bambusa balcooa (Mudai and Borthakur, 2009), Ocimum gratissimum (Gopi et al., 2006) and Mentha arvensis (Chishti et al., 2006).

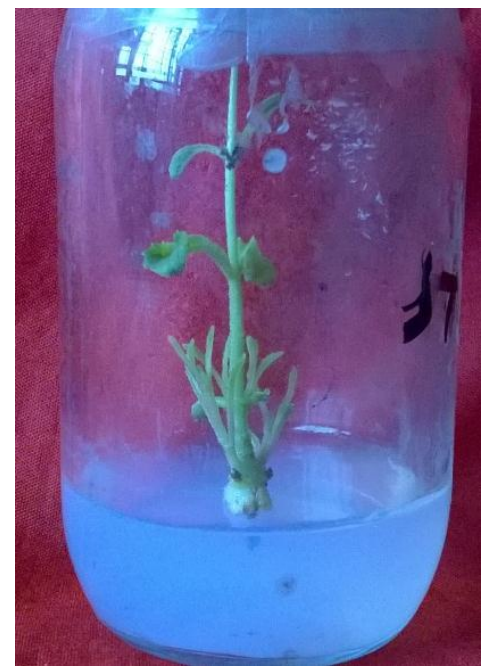

Figure 1. No. of shoots and length of shoots at $2 \mathrm{mgL}^{-1}$ BAP after 21 days. 
Table 1. Effect of BAP or Kn on shoot proliferation of Stevia rebaudiana.

\begin{tabular}{|c|c|c|c|}
\hline $\begin{array}{l}\text { BAP / Kinetin concentrations } \\
\left(\mathrm{mgL}^{-1}\right)\end{array}$ & Days to shoot initiation & Number of shoots vial ${ }^{-1}$ & Shoot regeneration $(\%)$ \\
\hline 0 & $3.332 \mathrm{~d}$ & $1.664 \mathrm{e}$ & $70.00 \mathrm{~b}$ \\
\hline BAP 1.0 & $4.250 \mathrm{c}$ & $2.500 \mathrm{~cd}$ & $80.00 \mathrm{a}$ \\
\hline BAP 2.0 & $4.750 \mathrm{bc}$ & $3.750 \mathrm{a}$ & $80.00 \mathrm{a}$ \\
\hline BAP 3.0 & $5.500 \mathrm{a}$ & $3.250 \mathrm{ab}$ & $80.00 \mathrm{a}$ \\
\hline BAP 4.0 & $5.000 \mathrm{ab}$ & $2.664 \mathrm{bcd}$ & $60.00 \mathrm{~b}$ \\
\hline Kn 1.0 & $4.664 \mathrm{bc}$ & $2.332 \mathrm{~d}$ & $60.00 \mathrm{~b}$ \\
\hline Kn 2.0 & $5.250 \mathrm{ab}$ & $2.500 \mathrm{~cd}$ & $80.00 \mathrm{a}$ \\
\hline Kn 3.0 & $5.500 \mathrm{a}$ & $3.000 \mathrm{bc}$ & $80.00 \mathrm{a}$ \\
\hline $\mathrm{Kn} 4.0$ & $5.500 \mathrm{a}$ & $2.500 \mathrm{~cd}$ & $40.00 \mathrm{c}$ \\
\hline$\overline{\mathbf{L S D}_{(0.05)}}$ & 0.629 & 0.578 & 3.13 \\
\hline $\mathrm{CV}(\%)$ & 10.05 & 16.71 & 3.53 \\
\hline Level of significance & $* *$ & $* *$ & $* *$ \\
\hline
\end{tabular}

In a column figures having similar and no letter(s) do not differ significantly at $5 \%$ level whereas figures with dissimilar letter(s) differ significantly as per DMRT at same level.

$\mathrm{DMRT}=$ Duncan's Multiple Range Test; LSD $=$ Least significant difference and CV= Coefficient of variation; **= Significant at $1 \%$ level of probability

\subsubsection{Shoot regeneration}

Shoot regeneration was significantly influenced by the effect of different concentrations of BAP or Kinetin where it varied from 40 to $80 \%$ (Table 1). From the Table 1, it was found that the treatment BAP $\left(1,2,3 \mathrm{mgL}^{-1}\right)$ and $\mathrm{Kn}$ (2-4 $\mathrm{mgL}^{-1}$ ) showed same regeneration percentage of shoot $(80.00 \%)$. On the other hand, treatment $4 \mathrm{mgL}^{-1} \mathrm{Kn}$ produced the lowest regeneration of shoot $(40 \%)$ which was statistically differed from all other treatment of the study. According to Mathur and Begum (2015), $2 \mathrm{mgL}^{-1}$ BAP gave the highest response (80\%).

\subsubsection{Length of shoot}

Statistically significant variation was observed among different treatments on the length of plantlets The length of plantlets varied from $6.7 \mathrm{~cm}$ to $4.768 \mathrm{~cm}$ (Figure 2). The longest length of shoots $(6.7 \mathrm{~cm})$ was recorded in $3 \mathrm{mgL}^{-1}$ BAP among all the treatments of both BAP and Kn. $2 \mathrm{mgL}^{-1} \mathrm{Kn}$ gave longest shoot $(5.9 \mathrm{~cm})$ among all the different concentration of $\mathrm{Kn}$ treatment and had statistically identical shoot length with $2 \mathrm{mgL}^{-1} \mathrm{BAP}$. The shortest length of shoot $(4.768 \mathrm{~cm})$ was observed in control $\left(0 \mathrm{mgL}^{-1}\right.$ hormone) which was statistically similar to $4 \mathrm{mgL}^{-1} \mathrm{Kn}^{(4.90)}$. Rest of the treatments had also four statistically identical shoot length which was observed in both case of BAP $(1,4$ $\left.\mathrm{mgL}^{-1}\right)$ and $\mathrm{Kn}\left(1,3 \mathrm{mgL}^{-1}\right)$. According to Hassanen and Khalil (2013) shoot length decreased by increasing $\mathrm{Kn}$ concentrations above $2.0 \mathrm{mgL}^{-1}$. Superiority of BAP over kinetin was also demonstrated by several workers (VanEck et al., 1990; Sen et al., 1991; Mishra et al., 1995).

Shekhawatat (2012) reported that, although the number of shoots induced was considerably higher, stunted growth was observed at higher concentrations of BAP (3-5 $\left.\mathrm{mgL}^{-1}\right)$. In most cases, BAP was found to be essential for growth and better than Kn for shoot induction (Tawari et al., 2010). Shahriyar et al., (2015) found the lowest percentage of shoot multiplication was $63 \%$ and length was $3 \mathrm{~cm}$ obtained in Murashige and Skoog $+0.3 \mathrm{mg} / \mathrm{l}$ gibberellic acid within 10-15 days.

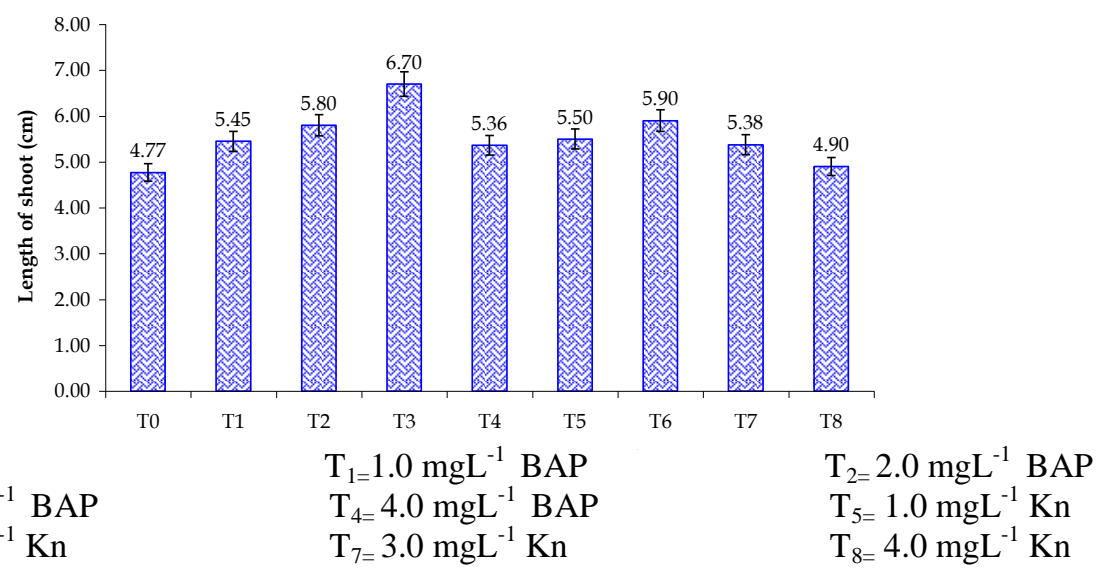

Figure 2. Effect of BAP or Kn on shoot proliferation of Stevia rebaudiana. 


\subsubsection{Days to shoot initiation}

The number of days required for shoot initiation varied significantly. There was a significant difference within the medium, for all observations. The most early shoot initiation was observed in 4.25 days from MS $+1 \mathrm{mgL}^{-1}$ BAP medium among all the treatments of different concentration of BAP or Kn except control. The highest days required for shoot initiation was found 5.5 days from three similar hormone concentration $\left(3 \mathrm{mgL}^{-1}\right.$ BAP and 3-4 $\mathrm{mgL}^{-1} \mathrm{Kn}$ ) which was statistically closely related to $4 \mathrm{mgL}^{-1} \mathrm{BAP}$ and $2 \mathrm{mgL}^{-1} \mathrm{Kn}$.

Although, BAP ( 2 and $\left.3 \mathrm{mgL}^{-1}\right)$ and $\mathrm{Kn}\left(2\right.$ and $\left.3 \mathrm{mgL}^{-1}\right)$ gave highest shoot regeneration, $2 \mathrm{mgL}^{-1} \mathrm{BAP}$ gave the best performance by taking into account all other parameters like percentage of shoot regeneration(80\%) along with average number of shoots per explants $(3.750)$, average length of shoot $(5.80 \mathrm{~cm})$ and days required to shoot regeneration ( 4.75 days).

\subsection{Combined effect of cytokinins (BAP and Kn) on shoot proliferation of Stevia rebaudiana after 4 week}

In the combined effect of treatments, the percentage of shoot regeneration, days required for shoot initiation, number of shoot per explant and length of shoot showed statistically significant.

\subsubsection{Shoot regeneration}

The highest percentage of shoot regeneration (100\%) was recorded in on MS medium supplemented with 1 $\mathrm{mgL}^{-1} \mathrm{BAP}+1 \mathrm{mgL}^{-1} \mathrm{Kn}$. Statistically similar shoot regeneration percentage $(83.33 \%)$ was observed in $0.5 \mathrm{mgL}^{-}$ ${ }^{1}$ BAP in combination with $0.5-2 \mathrm{mgL}^{-1} \mathrm{Kn}$. Lowest shoot regeneration percentage (50\%) was obtained in 1 $\mathrm{mgL}^{-1} \mathrm{BAP}$ in combination with $3 \mathrm{mgL}^{-1} \mathrm{Kn}$ which was statistically differed from other treatments.

\subsubsection{Number of shoots}

The highest number of shoots per explants (3.6) was found in $0.5 \mathrm{mgL}^{-1} \mathrm{BAP}+2 \mathrm{mgl}^{-1} \mathrm{Kn}$ which was closely related to $1 \mathrm{mgL}^{-1} \mathrm{BAP}+1 \mathrm{mgL}^{-1} \mathrm{Kn}$ and $1.0 \mathrm{mgL}^{-1} \mathrm{BAP}+2.0 \mathrm{mgL}^{-1} \mathrm{Kn}$ (Table 2). This result was supported by the finding of Alhady et al., (2011) who obtained the maximum number of proliferated shoots on MS medium supplemented with $2.0 \mathrm{mgL}^{-1} \mathrm{BAP}+0.5 \mathrm{mgL}^{-1} \mathrm{Kn}$. However, MS medium supplemented with $\mathrm{Kn}$ resulted in elongated shoots. Statistically identical number of shoots per explant was obtained in $T_{1}, T_{2}, T_{4}, T_{5}$ which gave 2.8, 3.0, 2.75 and 2.75 number of shoot respectively. The reason for higher number of shoots per explants might be due to uptake of nutrients easily of explant. This result was partially supported Mehta et al., (2012) who obtained best response was on medium containing $0.5 \mathrm{mgL}^{-1} \mathrm{BAP}+0.5 \mathrm{mgL}^{-1}$.

Table 2. Effect of treatment combinations of different BAP and Kn concentrations on shoot proliferation of Stevia rebaudiana.

\begin{tabular}{llll}
\hline BAP + Kinetin concentrations $\left(\mathbf{m g L}^{-1}\right)$ & Days to shoot initiation & Number of shoots vial & Shoot regeneration $(\%)^{-1}$ \\
\hline 0 & $3.500 \mathrm{~g}$ & $1.500 \mathrm{~d}$ & $66.67 \mathrm{c}$ \\
$0.5+0.5$ & $3.800 \mathrm{fg}$ & $2.800 \mathrm{bc}$ & $83.16 \mathrm{~b}$ \\
$0.5+1.0$ & $4.200 \mathrm{efg}$ & $3.000 \mathrm{bc}$ & $83.33 \mathrm{~b}$ \\
$0.5+2.0$ & $4.800 \mathrm{cde}$ & $3.600 \mathrm{a}$ & $83.33 \mathrm{~b}$ \\
$0.5+3.0$ & $5.500 \mathrm{c}$ & $2.750 \mathrm{bc}$ & $66.67 \mathrm{c}$ \\
$1.0+0.5$ & $4.500 \mathrm{def}$ & $2.750 \mathrm{bc}$ & $66.67 \mathrm{c}$ \\
$1.0+1.0$ & $5.167 \mathrm{~cd}$ & $3.333 \mathrm{ab}$ & $100.0 \mathrm{a}$ \\
$1.0+2.0$ & $6.750 \mathrm{~b}$ & $3.250 \mathrm{abc}$ & $66.67 \mathrm{c}$ \\
$1.0+3.0$ & $7.663 \mathrm{a}$ & $2.663 \mathrm{c}$ & $50.00 \mathrm{~d}$ \\
\hline LSD $(\mathbf{0 . 0 5 )}$ & $\mathbf{0 . 7 9 7}$ & $\mathbf{0 . 5 4 2}$ & $\mathbf{6 . 4 4 7}$ \\
CV $(\boldsymbol{\%})$ & $\mathbf{1 3 . 4}$ & $\mathbf{1 6 . 2 9}$ & $\mathbf{7 . 4 6}$ \\
Level of significance & $* *$ & $* *$ & $* *$ \\
\hline
\end{tabular}

In a column figures having similar and no letter(s) do not differ significantly at $5 \%$ level whereas figures with dissimilar letter(s) differ significantly as per DMRT at same level.

$\mathrm{DMRT}=$ Duncan's Multiple Range Test; LSD $=$ Least significant difference and $\mathrm{CV}=$ Coefficient of variation; $* *=$ Significant at $1 \%$ level of probability

\subsubsection{Days to shoot initiation}

The days required for shoot appearance was statistically significant ranged from 7.663 to 3.500 days (Table 2). The reason for varied duration to shoot appearance might be due to genetical make up of the genotypes. The minimum number of days required for shoot initiation was observed in control $\left(\mathrm{T}_{0}\right)$. The highest days required for shoot initiation was recorded in $1 \mathrm{mgL}^{-1} \mathrm{BAP}+3 \mathrm{mgL}^{-1} \mathrm{Kn}$. The days required for shoot initiation was increased with the increase of hormone concentration. 


\subsubsection{Shoot length}

The longest shoot length $(6.444 \mathrm{~cm})$ was observed in $0.5 \mathrm{BAP}$ in combination with $0.5 \mathrm{mgL}^{-1} \mathrm{Kn}$ (Table 2 and Figure 3) which was followed by $1 \mathrm{mgL}^{-1} \mathrm{BAP}+1 \mathrm{mgL}^{-1} \mathrm{Kn}(5.86 \mathrm{~cm})$. The lowest shoot length $(4.43 \mathrm{~cm})$ was recorded at $0 \mathrm{mgL}^{-1} \mathrm{BAP}+0 \mathrm{mgL}^{-1} \mathrm{Kn}$ which was preceded by $1 \mathrm{mgL}^{-1} \mathrm{BAP}+3 \mathrm{mgL}^{-1} \mathrm{Kn}(4.80 \mathrm{~cm})$. In the present study, gradual increase in shooting frequency, number of shoots per explant was observed with increasing concentrations of BAP in combination with $\mathrm{Kn}$. In a nutshell, it can be concluded that combination of $0.5 \mathrm{mgL}^{-1} \mathrm{BAP}$ and $2 \mathrm{mgL}^{-1} \mathrm{Kn}$ showed the best performance to all parameter. This study also similar to the result of Pawar et al., (2015). Mehta et al., (2012) reported that the maximum number of shoots (3.42 \pm 0.58$)$ was developed on MS media fortified with $0.5 \mathrm{BAP} \pm 2.0 \mathrm{Kn}$. According to Sridhar and Aswath (2014) the maximum regeneration frequency $(70 \%)$, shoot number $(5.0)$ and shoot length $(4.4 \mathrm{~cm})$ were observed in the combination of $2.0 \mathrm{mgL}^{-1} \mathrm{BAP}+0.5 \mathrm{mgL}^{-1} \mathrm{Kn}+0.1 \mathrm{mgL}^{-1}$ IAA. It can be concluded that with the increase of cytokinin hormone combination, number of shoot increased and length of shoot decreased. At higher concentration of hormone combination, it may be stunted growth of shoot.

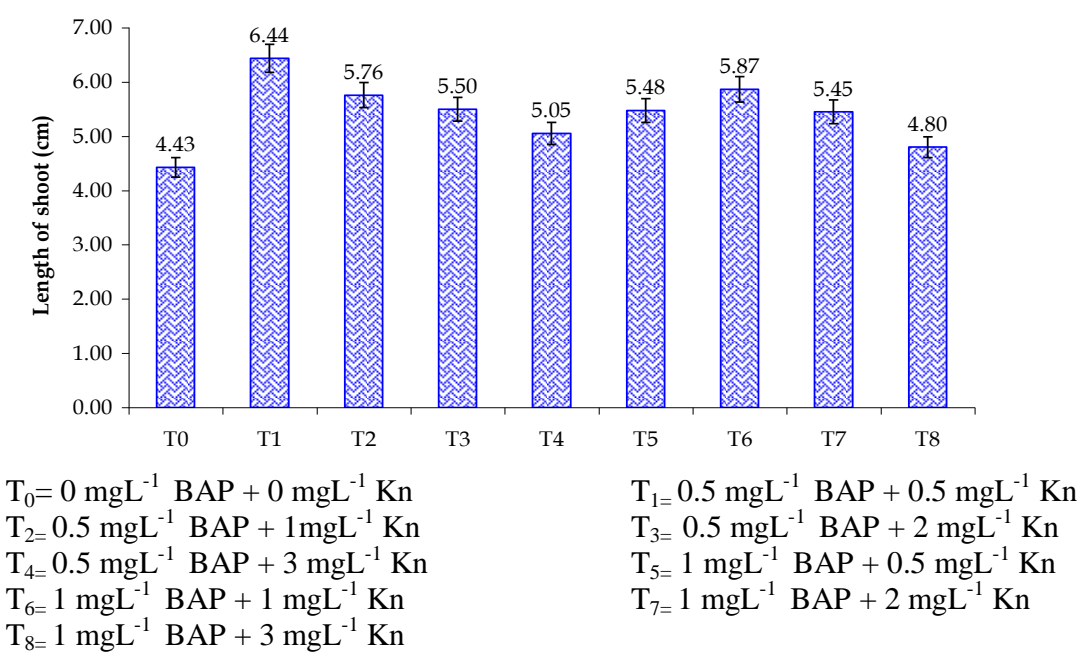

Figure 3. Effect of treatment combinations of different BAP and Kn concentrations on shoot proliferation of Stevia rebaudiana.

\subsection{Effect of different concentrations of TDZ on direct shoot regeneration of $S$. rebaudiana after 3 week 3.3.1. Shoot regeneration percentage}

The explants were inoculated with different concentrations of TDZ $\left(0.5,1.0,1.5,2.0 \mathrm{mgL}^{-1}\right)$ in combination with $1.0 \mathrm{mgL}^{-1} \mathrm{BAP}$ to observe their effect on shoot development and multiplication. The highest percentage (75\%) of explant showing shoot was recorded in TDZ at $0.5 \mathrm{mgL}^{-1}$ which was similar to TDZ 1.0 and $0 \mathrm{mgL}^{-1}$ (75\%). The lowest percentage of explants (50\%) showing shoot was recorded in 1.5 and $2.0 \mathrm{mgL}^{-1} \mathrm{TDZ}$ (Table 3). TDZ is a phenylurea type plant growth regulator, which was used earlier as a cotton defoliant (Arndt et al., 1976). Later, it was believed to exhibit strong cytokinin-like activity almost similar to that of N6-substituted adenine derivatives (Mok et al., 1982; Gyulai et al., 1995). It has been shown to induce shoot proliferation (Niewkerk et al., 1986).

Table 3. Effect of different concentrations of TDZ on shoot proliferation of Stevia rebaudiana.

\begin{tabular}{|c|c|c|c|}
\hline TDZ concentrations $\left(\mathrm{mgL}^{-1}\right)$ & Days to shoot initiation & Number of shoots vial ${ }^{-1}$ & Shoot regeneration $(\%)$ \\
\hline 0 & 6.332 & $2.665 \mathrm{e}$ & $75.00 \mathrm{a}$ \\
\hline 0.5 & 6.665 & $7.332 \mathrm{~d}$ & $75.00 \mathrm{a}$ \\
\hline 1.0 & 7.000 & $11.33 \mathrm{~b}$ & $75.00 \mathrm{a}$ \\
\hline 1.5 & 6.500 & $14.50 \mathrm{a}$ & $50.00 \mathrm{~b}$ \\
\hline 2.0 & 6.500 & $8.500 \mathrm{c}$ & $50.00 \mathrm{~b}$ \\
\hline$\overline{\mathbf{L S D}_{(0.05)}}$ & 0.836 & 0.836 & 4.172 \\
\hline $\mathrm{CV}(\%)$ & 8.22 & 6.12 & 4.17 \\
\hline Level of significance & NS & $* *$ & $* *$ \\
\hline
\end{tabular}

In a column figures having similar and no letter(s) do not differ significantly at $5 \%$ level whereas figures with dissimilar letter(s) differ significantly as per DMRT at same level.

$\mathrm{DMRT}=$ Duncan's Multiple Range Test; LSD $=$ Least significant difference and CV= Coefficient of variation; $* *=$ Significant at $1 \%$ level of probability and NS= not significant 


\subsubsection{Days required for shoot appearance}

The days required for shoot appearance differs non-significantly (Table 3). The explants treated with $1 \mathrm{mgL}^{-1} \mathrm{TDZ}$ took highest number days for shoot appearance (7.00 days) followed by $0.5,1.5$ and $2.0 \mathrm{mgL}^{-1} \mathrm{TDZ}$. But TDZ 0 $\mathrm{mgL}^{-1}$ (control) took lowest number days for shoot appearance (6.332 days).

\subsubsection{Number of shoot per explant}

Noticeable variation was observed among the treatments in respect of number of shoot per explants (Table 3). The highest number of shoots per explants (14.0) was recorded in $1.5 \mathrm{mgL}^{-1} \mathrm{TDZ}$ followed by $1.0 \mathrm{mgL}^{-1}$, $2.0 \mathrm{mgL}^{-1} \mathrm{TDZ}$ (Figures 4 and 5). The TDZ concentration more than $1.5 \mathrm{mgL}^{-1}$ reduced the number of shoot per explants. The lowest number of shoots were obtained from $\mathrm{T}_{0}$ (control contained only $1 \mathrm{mgL}^{-1} \mathrm{BAP}$ ). The higher concentrations of TDZ $\left(2.0 \mathrm{mgL}^{-1}\right)$ resulted depletion in shoot regeneration. Yucesan et al., (2007) reported that higher concentration of TDZ reduced number of shoots per explants. This was due to the adverse effect of higher concentration of TDZ. But in both parameters, values of shoot number parameter started to decline after the third level.

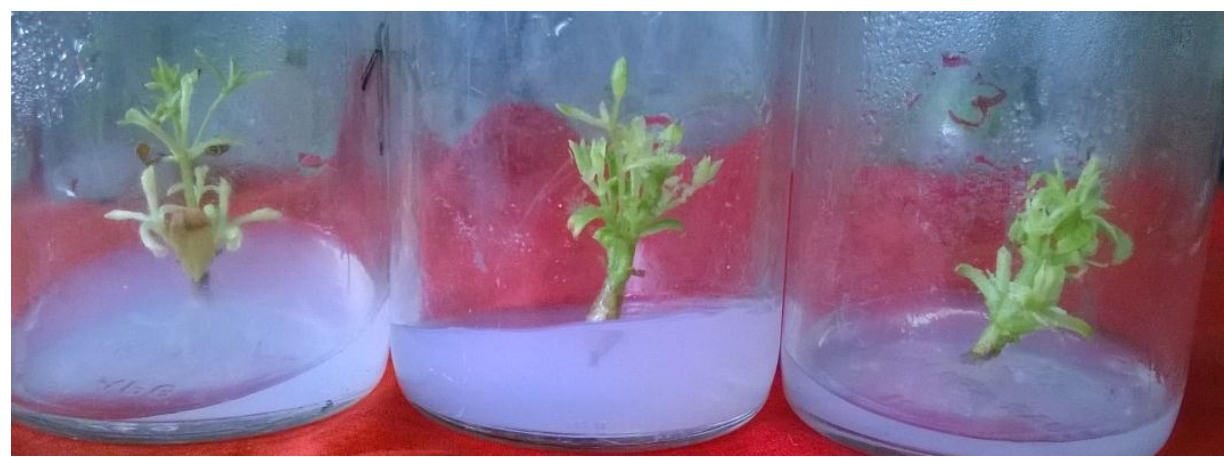

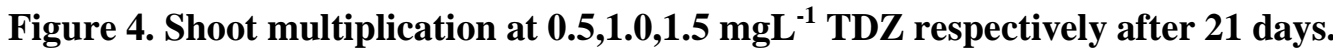

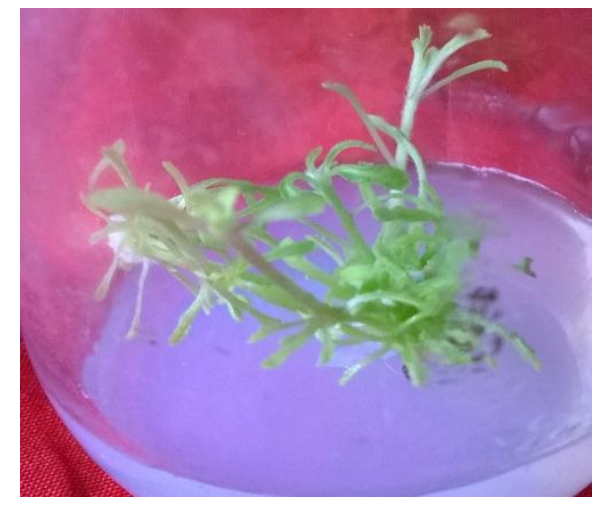

Figure 5. No. of shoots at $1.5 \mathrm{mgL}^{-1} \mathrm{TDZ}$.

\subsubsection{Shoot length}

Different levels of TDZ had significant effect on length of shoot (Figure 6). The longest length of shoot (5.033 $\mathrm{cm}$ ) was observed in control containing $1 \mathrm{mgL}^{-1} \mathrm{BAP}$ without TDZ. Length of shoot reduced with the increase of TDZ concentration. The longest shoot $(5.03 \mathrm{~cm})$ was measured in control $\left(\mathrm{T}_{0}\right)$ followed by TDZ $1 \mathrm{mgL}^{-1}(4.4$ $\mathrm{cm})$. The shortest length of shoot $(3.1 \mathrm{~cm})$ was noted in TDZ $2.0 \mathrm{mgL}^{-1}$. It is clear that an increase in TDZ concentration could promote the rate of shoot proliferation but there was a certain limitation. Moreover, the rising of shoot number might affect the length since the nutrients taken up were distributed to more shoots (Huy and Xuan-Mai, 2014). 


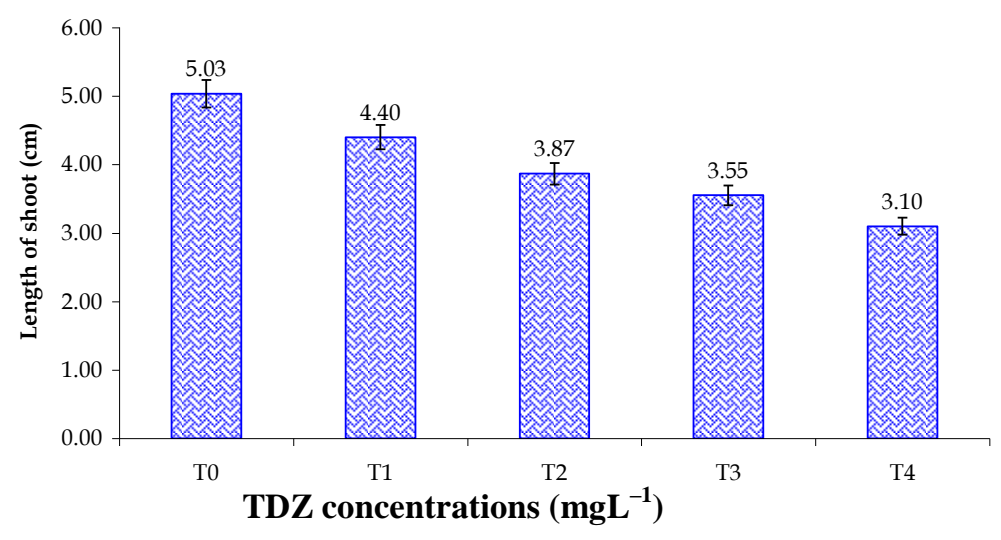

$$
\begin{array}{lll}
\mathrm{T}_{0}: 0 \mathrm{mgL}^{-1} \mathrm{TDZ} & \mathrm{T}_{1}: 0.5 \mathrm{mgL}^{-1} \mathrm{TDZ} & \mathrm{T}_{2}: 1.0 \mathrm{mgL}^{-1} \mathrm{TDZ} \\
\mathrm{T}_{3}: 1.5 \mathrm{mgL}^{-1} \mathrm{TDZ} & \mathrm{T}_{4}: 2.0 \mathrm{mgL}^{-1} \mathrm{TDZ} &
\end{array}
$$

Figure 6. Effect of different concentrations of TDZ on shoot proliferation of Stevia rebaudiana.

\subsection{Effect of Coconut water on shoot induction of $S$. rebaudiana after 3 week}

Coconut water is the colorless liquid endosperm of green coconuts (Cocos nucifera). Coconut water is the more complex combination of compounds than coconut milk (Molnar et al., 2011). To measure the effect of coconut water, explants were cultured on MS medium with four different concentrations: $20 \mathrm{mlL}^{-1}, 40 \mathrm{mlL}^{-1}, 60 \mathrm{mlL}^{-1}$ and $80 \mathrm{mlL}^{-1}$. Diphenylurea, a growth factor found in coconut water, exhibits cytokinin-like responses (Gnasekaran et al., 2010).

So, as a source of cytokinin, $20-80 \%$ coconut water was added to the medium. For number of shoot, the appropriate doses of coconut water for Stevia was $60 \mathrm{mlL}^{-1}$ in MS medium which gave maximum number of shoot $\left(7.332 \mathrm{~cm}\right.$ ) (Figure 7). Statistically similar number of shoot was obtained from $40 \mathrm{mlL}^{-1}$ and $80 \mathrm{mlL}^{-1}$ coconut water. The lowest number of shoots per explant (1.66)) was recorded in control. Control gave the longest length of shoot $(5.33 \mathrm{~cm})$ (Table 4). By comparing all the parameter of the coconut water treatment, the appropriate doses of coconut water for Stevia was $40 \mathrm{mlL}^{-1}$ in MS medium which gave longest length of shoot $(5.10 \mathrm{~cm}), 4.75$ number of shoot and required 5.7 days to shoot initiation (Table 4).

Highest percentage of shoot regeneration was obtained from 20 and $40 \mathrm{mlL}^{-1}$ coconut water which were similar to each other (Table 4). Kuraishi \& Okumura (1961) reported the cytokinin activity in fresh coconut water. This class of plant growth regulator has the main function to stimulate cell division, subsequently to morphogenesis. Some natural cytokinins have been isolated from coconut water, such, such as zeatin and N'-diphenyl urea (George, 2008), but levels of cytokinins and their specificity in coconut water are still unclear.

Table 4. Effect of different concentrations of coconut water along with $1.0 \mathrm{mgL}^{-1} \mathrm{BAP}+0.1 \mathrm{mgL}^{-1} \mathrm{NAA}$ on shoot proliferation of Stevia rebaudiana.

\begin{tabular}{lllll}
\hline Coconut water $(\mathbf{m l} / \mathbf{L})$ & $\begin{array}{l}\text { Days to shoot } \\
\text { initiation }\end{array}$ & $\begin{array}{l}\text { Number of shoots } \\
\text { vial }^{-1}\end{array}$ & $\begin{array}{l}\text { Length of shoot } \\
(\mathbf{c m})\end{array}$ & Shoot regeneration $(\%)$ \\
\hline 0 & $4.332 \mathrm{~d}$ & $1.664 \mathrm{~d}$ & $5.300 \mathrm{a}$ & $60.00 \mathrm{~b}$ \\
20 & $5.250 \mathrm{c}$ & $3.000 \mathrm{c}$ & $4.300 \mathrm{~b}$ & $80.00 \mathrm{a}$ \\
40 & $5.750 \mathrm{bc}$ & $4.750 \mathrm{~b}$ & $5.100 \mathrm{a}$ & $80.00 \mathrm{a}$ \\
60 & $6.332 \mathrm{ab}$ & $7.332 \mathrm{a}$ & $4.032 \mathrm{c}$ & $60.00 \mathrm{~b}$ \\
80 & $6.668 \mathrm{a}$ & $5.332 \mathrm{~b}$ & $3.632 \mathrm{~d}$ & $60.00 \mathrm{~b}$ \\
\hline LSD(0.05) & $\mathbf{0 . 6 9 5}$ & $\mathbf{0 . 7 1 2}$ & $\mathbf{0 . 2 5 2}$ & $\mathbf{6 . 7 0 4}$ \\
CV $(\%)$ & $\mathbf{9 . 1 5}$ & $\mathbf{1 2 . 0 2}$ & $\mathbf{4 . 2}$ & $\mathbf{7 . 3 5}$ \\
Level of significance & $* *$ & $* *$ & $* *$ & $* *$ \\
\hline
\end{tabular}

In a column figures having similar and no letter(s) do not differ significantly at $5 \%$ level whereas figures with dissimilar letter(s) differ significantly as per DMRT at same level.

$\mathrm{DMRT}=$ Duncan's Multiple Range Test; LSD $=$ Least significant difference and $\mathrm{CV}=$ Coefficient of variation; $* *=$ Significant at $1 \%$ level of probability 


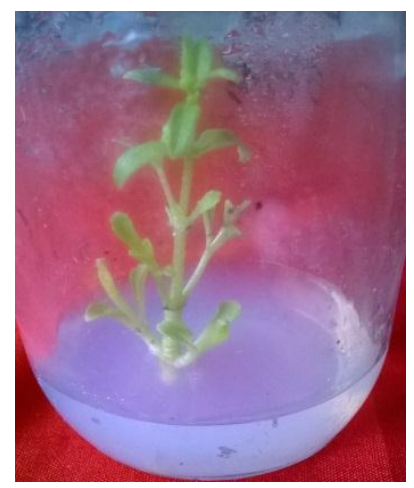

Figure 7. No. shoots and length of shoots at $60 \mathrm{mlL}^{-1}$ after 3 week

Peixe et al., (2007) also showed the positive effect of coconut water in vitro culture as substitute of Zeatin which is an important organic compound used in the process of micropropagation. This means that the supplementation of culture medium with coconut water can be beneficial to growth and morphogenesis of tissues, not only due the mineral nutrition that it provides but also because it is a source of natural growth regulators. The beneficial effect of coconut water was clearly observed on plant growth parameters such as shoot length, number of shoot (Table 4).

\subsection{Effect of auxin (NAA and IBA) on root induction of $S$. rebaudiana}

Formation of plantlet which was the aim of in vitro regeneration includes shoot formation followed by root initiation. Auxins (NAA) have characteristic feature of promoting cell division, stem elongation and rooting (Razdan, 2003). The regenerated shoots were implanted onto MS medium fortified with varying concentration of NAA $\left(1.0,1.5,2.0 \mathrm{mgL}^{-1}\right)$ and IBA $\left(1.0,1.5,2.0 \mathrm{mgL}^{-1}\right)$. Assessment of root formation was studied through the parameters percent of root initiation, days to root initiation and number of root formation per shoot and length of root. 4-cm-and-above shoots were transferred to rooting media in order to help the plants take up nutrients more efficiently (Table 5 and Figure 8). It was revealed from table 11 that, the MS medium without auxin was not useful for rooting. However, The highest percentage of root formation $(66.67 \%)$ was found in NAA $\left(1,1.5 \mathrm{mgL}^{-1}\right)$ and 1.0 $\mathrm{mgL}^{-1} \mathrm{IBA}$, where lowest percentage of root formation (33.33\%) was observed in $1.5 \mathrm{mgL}^{-1}, 2.0 \mathrm{mgL}^{-1} \mathrm{IBA}_{\text {and }}$ $2.0 \mathrm{mgL}^{-1}$ NAA which are same to one another (Table 5).

Different concentrations of NAA and IBA significantly affected the length of roots and number of roots. Both NAA and IBA at $1.0 \mathrm{mgL}^{-1}$ concentration gave the best response (66.67\%) in case of number of roots and length of roots (Figure 8). Between these two rooting hormones (IBA and IAA), IBA produced the higher number of roots (7.0) per shoot. MS media supplemented with $1 \mathrm{mgL}^{-1} \mathrm{NAA}$ ) were found to be the best for rooting in terms of rooting percentage $(66.67 \%)$ and days to root initiation $(9.5)$. Moreover, the longest root $(2.9 \mathrm{~cm})$ was recorded in $1 \mathrm{mgL}^{-1} \mathrm{IBA}$ followed by $1.5 \mathrm{mgL}^{-1} \mathrm{IBA}$ and the shortest root $(1.2 \mathrm{~cm})$ was recorded in $2 \mathrm{mgL}^{-1} \mathrm{NAA}$ (Figure 6). The highest number of root (7.0) was recorded in MS medium supplemented with $1.0 \mathrm{mgL}^{-1} \mathrm{IBA}^{-1}$ followed by 1.0 $\mathrm{mgL}^{-1}$ NAA (Figures 9 and 10). The lowest number of root was found in both $2 \mathrm{mgL}^{-1}$ NAA and IBA. No root was found at both $0 \mathrm{mgL}^{-1} \mathrm{NAA}$ and IBA.

Table 5. Effect of different concentrations of NAA or IBA on root formation of Stevia rebaudiana

\begin{tabular}{llll}
\hline NAA / IBA concentrations $\left(\mathbf{m g L}^{-\mathbf{1}}\right)$ & Days to root initiation & Number of roots shoot & Root formation $(\%)^{\mathbf{1}}$ \\
\hline 0 & $0.000 \mathrm{e}$ & $0.000 \mathrm{e}$ & $0.000 \mathrm{c}$ \\
NAA 1.0 & $9.500 \mathrm{~d}$ & $4.500 \mathrm{~b}$ & $66.67 \mathrm{a}$ \\
NAA 1.5 & $10.50 \mathrm{c}$ & $3.500 \mathrm{c}$ & $66.67 \mathrm{a}$ \\
NAA 2.0 & $12.00 \mathrm{~b}$ & $2.000 \mathrm{~d}$ & $33.33 \mathrm{~b}$ \\
IBA 1.0 & $10.50 \mathrm{c}$ & $7.000 \mathrm{a}$ & $66.67 \mathrm{a}$ \\
IBA 1.5 & $12.00 \mathrm{~b}$ & $3.000 \mathrm{c}$ & $33.33 \mathrm{~b}$ \\
IBA 2.0 & $16.00 \mathrm{a}$ & $2.000 \mathrm{~d}$ & $33.33 \mathrm{~b}$ \\
\hline LSD $(\mathbf{0 . 0 5})$ & $\mathbf{0 . 5 6 1}$ & $\mathbf{0 . 6 9 2}$ & $\mathbf{3 . 6 2 5}$ \\
CV (\%) & $\mathbf{3 . 6 4}$ & $\mathbf{1 4 . 3 7}$ & $\mathbf{5 . 5 2}$ \\
Level of significance & $* *$ & $* *$ & $* *$ \\
\hline
\end{tabular}

In a column figures having similar and no letter(s) do not differ significantly at $5 \%$ level whereas figures with dissimilar letter(s) differ significantly as per DMRT at same level.

$\mathrm{DMRT}=$ Duncan's Multiple Range Test; LSD $=$ Least significant difference and $\mathrm{CV}=$ Coefficient of variation; $* *=$ Significant at $1 \%$ level of probability. 


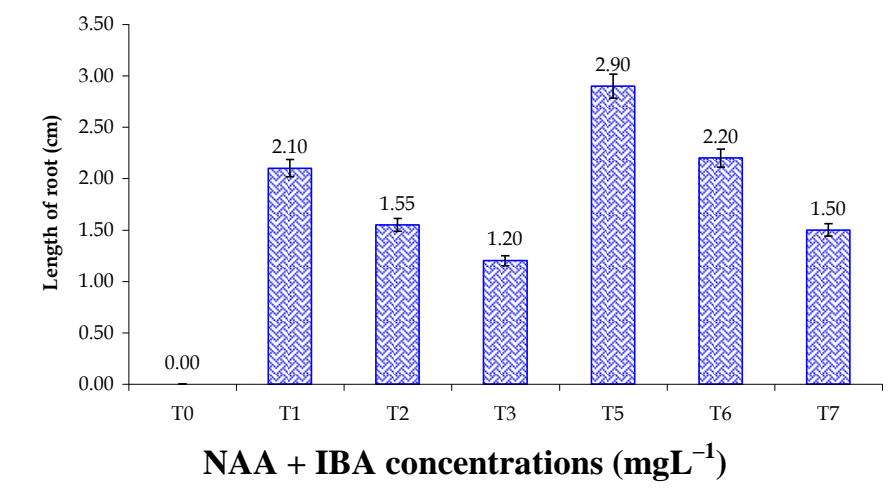

$$
\begin{array}{ll}
\mathrm{T}_{0}=0 \mathrm{mgL}^{-1} \mathrm{NAA}+0 \mathrm{mgL}^{-1} \mathrm{IBA} & \mathrm{T}_{1=} 1 \mathrm{mgL}^{-1} \mathrm{NAA}+0 \mathrm{mgL}^{-1} \mathrm{IBA} \\
\mathrm{T}_{2=1.5 \mathrm{mgL}^{-1} \mathrm{NAA}+0 \mathrm{mgL}^{-1} \mathrm{IBA}} & \mathrm{T}_{3=} 2.0 \mathrm{mgL}^{-1} \mathrm{NAA}+0 \mathrm{mgL}^{-1} \mathrm{IBA} \\
\mathrm{T}_{4=} 0 \mathrm{mgL}^{-1} \mathrm{NAA}+1 \mathrm{mgL}^{-1} \mathrm{IBA} & \mathrm{T}_{5=} 0 \mathrm{mgL}^{-1} \mathrm{NAA}+1.5 \mathrm{mgL}^{-1} \mathrm{IBA} \\
\mathrm{T}_{6=} 0 \mathrm{mgL}^{-1} \mathrm{NAA}+2 \mathrm{mgL}^{-1} \mathrm{IBA} &
\end{array}
$$

Figure 8. Effect of different concentrations of NAA or IBA on root formation of Stevia rebaudiana

The maximum days for root appearance were recorded on $2 \mathrm{mgL}^{-1} \mathrm{IBA}$. The minimum days required for root initiation was observed in $1 \mathrm{mgL}^{-1}$ NAA. Root induction gradually decreased with increasing concentrations of auxin of both NAA and IBA. NAA was less effective for root formation and promoting root extension. A significant difference was found on root length at different concentrations and combinations of growth regulators. There were noticeable differences in the morphology of roots from two different hormone treatments. IBA tended to develop thick and hairy fibrous roots while NAA gave rise to less hairy and thin roots. MS liquid medium containing $1.0 \mathrm{mgL}^{-1}$ IBA produced a greater number of healthy and sturdy roots than those cultured with NAA (Nagesh, 2008).

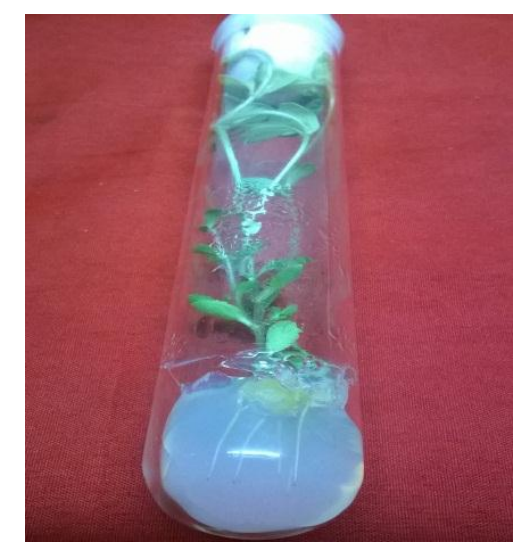

Figure 9. No. roots and length of roots at $1 \mathrm{mgL}^{-1} \mathrm{NAA}$ after 3 week
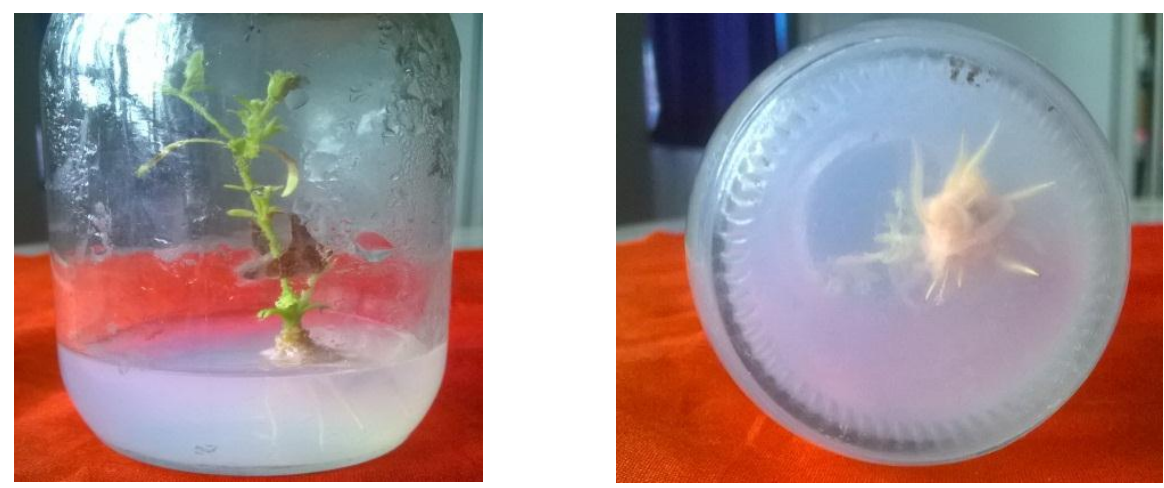

Figure 10. No. roots and length of roots at $1 \mathrm{mgL}^{-1} \mathrm{IBA}$ after 3 week 


\section{Conclusions}

Present studies were conducted with a view to evaluate the effect of different concentration of cytokinin hormone (BAP, Kn, Thidiazuron), coconut water on shoot regeneration and the effect of different concentration of auxins (NAA and IBA) on root formation. Micropropagation technology of Stevia rebaudiana has been briefly analyzed. Thus, this protocol could be helpful to establish and cultivate stevia as a promising newly introduced non-caloric sweetener and anti-diabetic medicinal plant in Bangladesh.

\section{Conflict of interest}

None to declare.

\section{References}

Ahmed MB, M Salahin, R Karim, MA Razvy, MM Hannan, R Sultana, M Hossain and R Islam, 2007. An Efficient Method for in vitro Clonal Propagation of a Newly Introduced Sweetener Plant (Stevia rebaudiana) in Bangladesh. American-Eurasian Journal of Scientific Research, 2: 121-125.

Alhady MRAA, 2011. Micropropagation of Stevia rebaudiana Bertoni. A New Sweetening Crop in Egypt. Global Journal of Biotechnology and Biochemistry, 6: 178-182.

Arndt F, R Rusch and HV Stillfried, 1976. A new cotton defoliant. Plant Physiol, pp. 57-99.

Chalapathi MV and S Thimmegowda, 1997. Natural non-calorie sweetener Stevia (Stevia rebaudiana Bertoni), A future crop of India. Crop Research Hisar, 14: 347-350.

Chishti N, AS Sahwl, ZA Kaloo, MA Bhat and P Sultan, 2006. Clonal propogation of Mentha arvensis L. through nodal explants. Pakistan Journal of Biological Sciences, 9: 1416-1419.

George EF, 2008. Plant propagation by tissue culture. 3. ed. Great Britain: Exegetics, p.479.

Gnasekaran P, X Rathinam, UR Sinniah and S Subramaniam, 2010. A study on the use of organic additives on the protocorm-like bodies (plbs) growth of Phalaenopsis violacea orchid. Journal of Phytology, 2: 29-33.

Gopi C, YN Sekhar and Ponmuragan, 2006. In vitro multiplication of Ocimum gratissimum L. through direct regeneration. African Journal of Biotechnology, 5: 723-726.

Gyulai G, Z Jekkel, J Kiss and LE Heszky, 1995. A selective auxin and cytokinin bioassay based on root and shoot formation in vitro. J Plant Physiol., 145: 379-382.

Hassanen SA and RMA Khalil, 2013. Biotechnological Studies for Improving of Stevia (Stevia rebaudiana Bertoni) in vitro Plantlets. Middle-East Journal of Scientific Research, 14: 93-106.

Huy NT and TT Xuan-Mai, 2014. Investigation of Effective In Vitro Propagation Media for Stevia rebaudiana Bertoni. KKU Research Journal, 19: 172-180.

Kavitha MS, EG Wesely and P Mehalingam, 2012. Direct multiple shoot regeneration from Shoot tip and nodal explants of Solanum Nigrum L. A Medicinal Herb. Journal of Ornamental and Horticultural Plants, 2: 65-72.

Kuraishi S and FS Okumura, 1961. A new green-leaf growth stimulating factor, phyllococosine, from coconut milk. Nature, 189: 148-149.

Mathur M and T Begum, 2015. Shootlets Regeneration and Tissue Culture Studies on Stevia rebaudiana Bertoni and Terminalia bellerica Roxb. International Journal of Recent Biotechnology, 3: 25-35.

Mehta J, S Khan, V Bisht, M Syedy, R Rathore and L Bagari, 2012. High frequency Multiple shoots regeneration and callus induction an anti diabetic plant-Stevia rebaudiana Bertoni-An important medicinal plant. American Journal of Pharmtech Research, 2: 19-27.

Midmore JD and AH Rank, 2006. An intense natural sweetener-laying the ground work for a new rural RIRDC Publication No 06/020 RIRDC Project No UCQ-17A.

Mok MC, DWS Mok, DJ Armstrong, K Shudo, Y Isogai and T Okamoto, 1982. Cytokinin activity of N-phenylN-1,2,3-thiadiazol-5-ylurea (thidiazuron). Phytochemistry, 21: 1509-1511.

Molnar Z, E Virag and V Ordog, 2011. Natural Substances in tissue culture media of higher plants. Acta Biologica Szegediensis 55: 123-127.

Mudoi KD and M Borthakur, 2009. In vitro microprpogation of Bambusa balcooa Roxb. through nodal explants from field grown clums and scope for upscaling. Curr. Sci., 96: 963-966.

Nagesh KS, 2008. High Frequency Multiple Shoot Induction of Curculigo orchioides Gaertn. Shoot Tip V/S Rhizome Disc Taiwania, 53: 242-247.

Neves LO, L Tomaz and MPS Favereiro, 2001. Micropropogation of Medicago truncatula Gaertn. c.v. Jemalong and Medicago trumculata ssp. narbonensis. Plant Cell Tissue and Organ Culture, 67: 81-84.

Niewkerk V, IPRH Zimmerman and I Fordham, 1986. Thidiazuron stimulation of apple shoot proliferation in vitro. Horticulture Science, 21: 516-518. 
Papry M , Ahsan SM and Shahriyar S, 2015. In vitro regeneration protocol development via callus formation from stem explant of tomato. Asian J. Med. Biol. Res., 1: 589-599.

Pawar SV, VG Khandagale, VM Jambhale, AS Jadhav and BD Pawar, 2015. In vitro regeneration studies in Stevia through nodal segment and shoot tip. The Bioscan, 10: 1007-1010.

Peixe A, 2007.Coconut water and BAP successfully replaced zeatin in olive (Olea europaea L.) micropropagation. Scientia Horticulturae, pp. 113 1-7.

Razak UNAA, OC Boon, YT Sing and LL Kiaw 2014. In vitro Micropropagation of Stevia rebaudiana Bertoni in Malaysia Chong Boon Ong. Brazilian Archives of Biology and Technology, 57: 23-28 .

Razdan MK, 2003. Introduction to Plant Tissue. 2nd Edition. Qxford \& IBH Publishing Co. Pvt. Ltd. New Delhi. pp. 27-9.

Sahoo Y and PK Chand, 1998. In vitro multiplication of medical herb Tridax procumbens L. (Mexican daisy, coat button) influence of explanting season, growth regulator, synergy, culture passage and passing substrate. Phytomorphology, 48: 195-205.

Satpathy S and M Das, 2010. In vitro shoot multiplication in Stevia rebaudiana bert., a medicinally important plant. General and Applied Plant Physiology, 36: 167-175.

Savita SM, K Sheela and S Sunanda, 2004. Stevia Rebaudiana- A functional Component for Food Industry. Journal of Human Ecology, 15: 261-264.

Shahriyar S, S Akram, K Khan, MF Miya and MAR Sarkar, 2015. In vitro plant regeneration of potato (Solanum tuberosum L.) at the rate of different hormonal concentration. Asian J. Med. Biol. Res., 1: 297303.

Shekhawat MS, 2012. Direct shoots regeneration from nodal meristems of Brugmansia suaveolens (Humb. and Bonpl. ex Wild.) Bercht. and J.Presl., The Pharma Innovation, 1: 50-56.

Sridhar TM and CR Aswath, 2014. Influence of Additives on Enhanced in Vitro Shoot Multiplication of Stevia rebaudiana (Bert.) - An Important Anti Diabetic Medicinal Plant. American Journal of Plant Sciences, 5: 192-199.

Taware AS, DS Mukadam, AM Chavam and SD Taware, 2010. Comparative studies of in vitro and in vivo grown plants and callus of Stevia Rebaudiana. International Journal of Integrative Biology, 1: 10.

Uddin MS, MSH Chowdhury, MMMH Khan, M Belal, R Ahmed and MA Baten, 2006. In vitro propagation of Stevia rebaudiana Bert in Bangladesh. Afr. J. of Biotech., 5: 1238-1240.

Yan N, H Hu, JL Huang, K Xu, H Wang and ZK Zhou, 2006. Micropropogation of Cypripedium flavum through multiple shoots of seedings derived from multiple seeds. Plant Cell Tissue Organ Culture, 84: 114-118.

Yucesan B, AU Turker and E Gurel, 2007. TDZ induced high frequency plant regeneration through multiple shoot formation in witloof Chicory (Cichorium inlybus L.). Plant Cell Tissue and Organ Culture, 91: 243250. 